\title{
Relief Valve Device
}

National Cancer Institute

\section{Source}

National Cancer Institute. Relief Valve Device. NCI Thesaurus. Code C50256.

A valve designed to automatically open in order to maintain the pressure in a system below a specified pressure. 